\title{
KISVÁROSI FUNKCIÓK VIZSGÁLATA A DÉLKELET-ALFÖLD EGYIK TELEPÜLÉSCSOPORTJÁN
}

\author{
Dr. Ph.D. Zsótér Brigitta \\ föiskolai docens, Szegedi Tudományegyetem Mérnơki Kar, Szeged
}

\begin{abstract}
SUMMARY
In my thesis the functions of four provincial towns in the south-east of the Great Hungarian Plain. According to the article by Zoltán Dövényi and Zoltánné Dövényi (1982) published in "Békési Élet" the urban functions were attended to by the four settlements - Battonya, Medgyesegyháza, Mezöhegyes, Mezökovácsháza - collectively. Although Tótkomlós is not mentioned in the article, it is important to examine because of its geographical proximity.In the course of my literary overview I outline the indispensable technical knowledge of the topic and the necessary methods applied in my research. The bases of my study were the research methods of Sándor Kókai, conducted in SzabolcsSzatmár-Bereg county. In my research I have come to the conclusion that the diversification remained but the functions have expanded to a certain extent.
\end{abstract}

\section{BEVEZETÉS}

A kutatásaim során öt délkelet-alföldi település városi funkcióit vizsgáltam. 1982-ben Dövényi Zoltán és Dövényi Zoltánné (1982) a Békési Élet címü folyóiratban megjelent cikkük szerint, négy délkelet-alföldi település: Battonya, Medgyesegyháza, Mezőhegyes és Mezőkovácsháza hasonló fejlettségüek és nagyjából egyidőben kellett volna várossá nyilvánítani öket, de a gyakorlat nem ezt igazolta. A cikk szerint az említett települések a földrajzi közelség miatt a városi funkciókat közösen látták el. Városi funkciónak nevezzük egy város azon közintézményeit, illetve szolgáltatásait, amelyek jellemzően meghatározzák a város arculatát. Beluszky Pál (1999) szerint egy városnak lehet központi-, ipari-, mezőgazdasági-, közlekedési-, turisztikai-, illetve lakó-tartózkodási funkciója. Egy városra jellemző lehet a felsoroltak közül egy, de akár több funkció különböző variációja is (Beluszky 1999). Ezek alapján Battonya töltötte be a jogbiztonság (Maday 1960) (Takács 1998), oktatás, sport és közmüvelödés funkcióit. Mezökovácsházához tartozott az egészségügy, igazgatás, szociális müködés felügyelete (Mucsi Tné 2001)(Dövényiné, Dövényi 1982). Mezöhegyesnek a mezögazdaságban (Enyedi 1960), az iparban (Krajkó 1974), valamint a szakmunkásképzésben volt jelentős része (Zsótér 2008) mindamellett, hogy a vadászathoz, a lovassportokhoz, illetve a turizmushoz is köze volt (Zsótér 2007). Habár Dövényiék (1982) cikke akkoriban még nem említette Tótkomlóst, a jelenlegi kutatás szempontjából fontos megemlíteni. Batonyának jelentös turisztikai, oktatásbeli múltja van, azon kívül, hogy a település arculatát meghatározza a szlovák-magyar nemzetiségü lakosság.

Célom tehát, hogy a kutatás végeztével megválaszoljam, hogy a funkcióbeli megosztottság máig is érvényes-e.

\section{ANYAG ÉS MÓDSZER}

Az interjúzás módszerét választottam, mert véleményem szerint a kutatás szempontjából a települések jegyzőinek, illetve aljegyzőinek a személyes megkeresés volt a legmegfelelöbb módszer (Kvale 1996) (Schleicher 2007) (Szokolszky 2004).

\section{SAJÁT VIZSGÄLAT}

Saját kutatásomat Kókai Sándor (2007) a Nyírségben elvégzett munkája alapján készítettem, melynek alapja a városi funkciók vizsgálata. A kutatás célja, hogy a már bevezetésben említett, az adott városra jellemzö funkciók változtak-e, és ha igen, milyen 
irányban. Kókai (2007) a funkciókat két részre osztotta, ezek a középvárosi és kisvárosi intézmények. A városok lélekszáma meghatározza, hogy milyen funkciók jelennek meg. $\mathrm{E}$ szerint a kis- és középvárosok lélekszáma 10-25 ezer fö, a kisvárosoké 5-10 ezer fö, és a törpe városoké 5 ezer fö alatti.

1. táblázat. A vizsgált települések lakossága 2009-ben (fö)

\begin{tabular}{|c|c|c|c|c|c|}
\hline Város & Battonya & Medgyesegyháza & Mezöhegyes & Mezökovácsháza & Tótkomlós \\
\hline Lakosság & 5838 & 3848 & 5408 & 6304 & 6049 \\
\hline
\end{tabular}

Forrás: KSH

Az 1. táblázat a 2009. január 1-i adatok szerint egyedül Medgyesegyháza számit törpevárosnak a vizsgált települések közül. A vizsgálathoz szükséges adatokat szóbeli interjú útján gyüjtöttem be, az egyes interjúalanyok, mint már emlitettem a vizsgált települések jegyzöi, illetve aljegyzöi voltak. Az interjúk során a Kókai Sándor-féle táblázatba (2007) rögzítettem az adatokat. Sajnos számításba kell venni a térségben, a rendszerváltást követö nagyarányú elvándorlást, mely komolyan befolyásolta a helyi funkciók szúkülését. A lakosság változásának vizsgálata a Kókai-féle módszer része ennek adatait a 2. táblázat mutatja.

2. táblázat. A vizsgált települések népességszámának alakulása (1990-2009) (fõ)

\begin{tabular}{|l|c|c|c|c|c|}
\hline Város & 1990 & 1995 & 2000 & 2005 & 2009 \\
\hline Battonya & 7385 & 6823 & 6482 & 6610 & 5838 \\
\hline Medgyesegyháza & 4340 & 4218 & 4002 & 3987 & 3848 \\
\hline Mezöhegyes & 7100 & 6670 & 6324 & 6022 & 5408 \\
\hline Mezökovácsháza & 7016 & 7329 & 7042 & 6773 & 6304 \\
\hline Tótkomlós & 7128 & 7109 & 6869 & 6486 & 6049 \\
\hline
\end{tabular}

Forrás: KSH

A 2. táblázatban is jól követhetö, hogy az adott települések lakossága a rendszerváltás után jelentősen lecsökkent. A csökkenés fokozatosnak tekinthetö, amely a mai napig sem állt meg. Mezökovácsházán viszont egy idöszakos növekedés is felfedezhetö. A nagyarányú csökkenés a munkahelyek tömeges elvesztésével indokolható ezzel, felerősítve a nagyvárosok felé irányuló migrációt. Ez már jóval korábban is tapasztalható volt, melyet a neves elödök is leírtak (Krajkó, Döbrönte, Mészáros 1978). Mezöhegyesen csak lendített a csökkenésen, hogy a cukorgyár 1997-ben véglegesen bezárt (Zsótér 2010).

\subsection{KÖZÉPVÁROSI INTÉZMÉNYEK VIZSGÁLATA}

A vizsgált települések minden ellátást kielégítő kórházzal az eddigiekben sem rendelkeztek. A kötelezö háziorvosi ellátás mellett szülöotthon müködött Battonyán, Medgyesegyházán, Mezöhegyesen és Tótkomlóson, amelyek a rendszerváltás után, részben a nagymértékü elvándorlás miatt bezártak. Jelenleg háziorvosi ellátáson túl Mezöhegyesen müködik egy krónikus belgyógyászati osztály, Mezőkovácsházán egy járóbeteg-ellátó szakrendelö, Medgyesegyházán egy „kis labor” található, ahol egyszerübb vizsgálatokat végeznek el, az összetettebb vizsgáltakat a gyulai Pándy Kálmán Kórház és a békéscsabai Réthy Pál Kórház végzi.

Battonyán és Mezöhegyesen nincs kirendeltsége az Agrárkamarának, a további három vizsgált településen viszont egy-egy szaktanácsadó áll az ügyfelek rendelkezésére. FVM hivatal egyik településen sincs (3. táblázat), a megyei kirendeltség Békéscsabán van. A falugazdász területközpont Mezőhegyesen található. A települések közül Mezőkovácsházán 
található APEH kirendeltség, illetve egy ügyfélszolgálati iroda Battonyán. ÁNTSZ iroda egyik településen sem üzemel, egyedül Mezőkovácsháza ad helyet a megyei kirendeltségnek.

3. táblázat. A vizsgált települések középvárosi funkciói

\begin{tabular}{|c|c|c|c|c|c|}
\hline Megnevezés & $\underset{5}{5}$ & 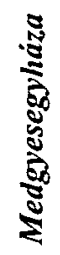 & $\frac{5}{8}$ & 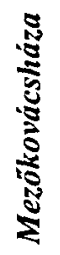 & \\
\hline Kórház & - & - & + & + & - \\
\hline Agrárkamara & - & + & - & $?$ & + \\
\hline FVM hivatal & - & - & - & - & - \\
\hline APEH iroda & - & - & - & + & - \\
\hline ANTSZ iroda & - & - & - & + & - \\
\hline Biztosító & + & + & + & + & + \\
\hline Bíróság & + & - & - & - & - \\
\hline Ügyészség & + & - & - & - & - \\
\hline Ügyvédi munkaközösség & + & - & + & + & - \\
\hline Közjegyzö.iroda & + & - & - & - & - \\
\hline Könyvelö iroda & + & + & + & + & + \\
\hline Ipartestület & - & - & - & + & + \\
\hline Vám- és pénzügyi központ & - & - & - & - & - \\
\hline Állami Közút Kht. & - & - & - & - & - \\
\hline VOLÁN pályaudvar & + & + & + & + & + \\
\hline Gépjármü értékesítö & - & - & - & + & - \\
\hline Idegenforgalmi Hivatal & - & - & + & - & + \\
\hline Környezetvéd. és Viz. Igazg. & + & - & - & - & - \\
\hline Telekom iroda & - & - & + & + & + \\
\hline Városi TV & - & - & - & - & + \\
\hline Távhószolgáltatảs & - & - & + & - & - \\
\hline Nyelviskola & - & - & - & - & - \\
\hline Rendörkapitányság & + & - & - & + & - \\
\hline Muzeális intézmény & + & + & - & - & - \\
\hline
\end{tabular}

Forrás: saját gyüjtésü adatok 
A településeken a biztosítók egyéni üzletkötök, akik vállalkozásban dolgoznak Tótkomlóson, illetve Mezőkovácsházán üzemeltetnek irodát.

Az ügyészség, bíróság és a közjegyzöi iroda Battonyán foglal helyet. Ez a magyarázata annak, hogy az igazságszolgáltatás funkcióját ez a település látja el a térségben.

Ügyvédi munkaközösségek nincsenek a városokban, az ügyvédek saját vállalkozásban dolgoznak. Könyvelöi irodák minden településen megtalálhatók. Ipartestület egyedül már csak Tótkomlóson létezik.

A településeken vám- és pénzügyi központ, illetve Állami Közútkezelö Kht. kirendeltsége nem található. A VPOP-nak korábban volt kirendeltsége Battonyán.

Kiépített buszpályaudvarral Mezökovácsháza, Battonya és Tótkomlós rendelkezik. A további településeken inkább buszfordulók vannak. Tótkomlóson nemrég fejeződött be a buszpályaudvar felújitása.

Vasúton mindegyik település megközelithetö. A pályaszakaszok több helyen is igen rossz állapotban vannak, de felújításuk egyelöre nincs tervbe véve.

Gépjármü-értékesítés a településeken Mezőkovácsháza kivételével nem folyik. Itt egy használtautó kereskedés müködik. Autószalonok legközelebb Makón, Orosházán és Békéscsabán találhatók.

Idegenforgalmi hivatal nem található, kizárólag Mezőhegyesen a Tourinform iroda, illetve Battonyán és Tótkomlóson E-pont, mely Pályázati követelmény volt. Medgyesegyházán is volt turisztikai iroda, de kihasználatlanság miatt megszünt.

Környezetvédelmi és Vízgazdálkodási igazgatóságnak kihelyezett szakaszmérnöksége üzemel Battonyán.

Telekom iroda üzemel jelenleg is Mezöhegyesen, Tótkomlóson és Mezőkovácsházán is. Battonyán kizárólag csak telefontornyok vannak, irodák viszont nincsenek. A kábeltelevizió és internet szolgáltatáson több szolgáltató osztozik az öt településen.

Városi televizió 100\%-os önkormányzati tulajdonban már csak Tótkomlóson van, a többi településen privatizálták, így a testületi üléseket és a képújságot a kábeltévé-szolgáltató sugározza.

Mezöhegyesen a kép némileg árnyaltabb volt. Itt a kábelsugárzást kezdetben a Parabola non-profit egyesület végezte. A cég a teljes hálózatot kiépitette a településen, de bevételeik csak a kiadásokat fedezték. Ezért az 1997. február 20-i közgyúlésen került sor a cég vagyonának ingyenes átadására. Az ủj tulajdonos ezután Mezőhegyes város önkormányzata lett. Ezután megalapításra került a Mezöhegyesi Városi Televízió Kht. Önkormányzati kézből a kábeltelevizió 2004-ben került ki. Indoka a veszteséges üzemeltetés volt, így új tulajdonosa a Bács-Kábel lett (Zsótér, Türkössy, Gálné 2007).

Távhöszolgáltatás kizárólag csak Mezőhegyesen érhető el. Régebben Battonyán is volt, de a nagymértékü tartozások miatt ezt felszámolták.

Nyelviskola egyik településen sem üzemel, a nyelvoktatás az általános és középiskolákban, illetve magántanároknál folyik.

Két településen, Battonyán és Mezőkovácsházán található rendőrkapitányság a többi településen rendörörsök vannak.

Muzeális intézmény több helyen is található. Ezek leginkább helytörténeti kiállítások, de Mezöhegyesen található egy kocsi múzeum, Tótkomlóson tájház, Battonyán müvészeti kiállítóhely, illetve a Medgyesegyházán és a hozzá tartozó Bánkúton egy emlékház.

\subsection{KISVÁROSI INTÉZMÉNYEK VIZSGÁLATA}

Az oktatási lehetőségek nagyon szerteágazóak a régióban, mely a 4. táblázaton is jól végigkövethető. Egyedül Medgyesegyháza nem rendelkezik középfokú oktatási intézménnyel. A Battonyai Mikes Kelemen Gimnáziumban a gimnáziumi mellett szakközépiskolai képzések is indulnak. 
4. táblázat. A vizsgált települések kisvárosi funkciói

\begin{tabular}{|c|c|c|c|c|c|c|c|c|c|c|c|c|c|c|c|c|}
\hline \multirow[b]{2}{*}{ 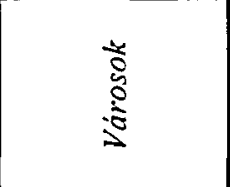 } & \multicolumn{3}{|c|}{ Oktatás } & \multicolumn{3}{|c|}{ Egészségügy } & \multicolumn{3}{|c|}{ Bank és pénzügy } & \multirow[b]{2}{*}{ 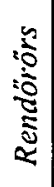 } & & \multirow[b]{2}{*}{ 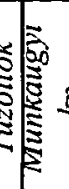 } & \multirow[b]{2}{*}{$\frac{5}{5}$} & \multirow[b]{2}{*}{ है } & & \multirow[b]{2}{*}{ 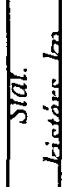 } \\
\hline & & 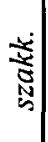 & 政 & 这 & $\begin{array}{l}u \\
\cdots \\
v\end{array}$ & 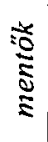 & $\stackrel{\Xi}{\Xi}$ & 5 & 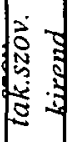 & & & & & & & \\
\hline Battanua & \pm & \pm & & \pm & & & OTP & & \pm & \pm & & $=$ & \pm & \pm & \pm & \\
\hline Medoreseonházo & & - & & & & & $O T P$ & & \pm & \pm & & 二 & $=$ & \pm & + & \\
\hline Mezöheoves & - & + & \pm & - & & & $O T P$ & & \pm & \pm & ב & $=$ & \pm & \pm & \pm & \\
\hline Ale=äkavácsháza & \pm & 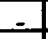 & & \pm & \pm & \pm & OTP & & \pm & - & \pm & \pm & \pm & \pm & \pm & \\
\hline Tórkamlós & \pm & & & + & & & OTP & & + & + & & & & & \pm & \\
\hline
\end{tabular}

Mezöhegyesen a Harruckern János Közoktatási Intézményen belül léteznek szakközépiskolai és szakmunkás képzések is. Az intézmény tagja az öt iskola egyesüléséből létrejött Harruckern János Közoktatási Intézménynek, melynek székhelye Gyula, és közel 3600 tanulója és 560 pedagógusa van.

A mezőkovácsházi Hunyadi János Közoktatási Intézmény kínál gimnáziumi, szakiskolai, szakközépiskolai, művészeti képzéseket, és mindemellett felnöttképzésre is lehetöség van. érhetök el.

Tótkomlóson a Jankó János Általános és Gimnáziumban gimnáziumi képzések

Az egészségügyi funkciókat tekintve a régióban három szakrendelö található. Ezek Battonyán, Mezökovácsházán és Tótkomlóson találhatóak. Az öt település közül a mentöállomás és a tüdőgondozó is Mezőkovácsházán található. Tótkomlóson tervben van egy új mentöállomás kiépítése.

Bankfiók mindegyik településen elérhetö. A települések mindegyikén található egy OTP fiók, Mezőkovácsházán és Tótkomlóson egy-egy K\&H fiók is.

Takarékszövetkezeti központ egyik településen sem található. Mezőhegyes és Tótkomlós a Gádoros és Vidéke Takarékszövetkezethez, a további települések a Kevermes és Vidéke Takarékszövetkezethez tartoznak.

Rendörörsök Mezőkovácsháza kivételével mindegyik településen találhatók. Itt a körzeti kapitányság foglal helyet. Tüzoltó parancsnokság Mezökovácsházán, önkéntes tüzoltóság Tótkomlóson és Battonyán is található.

Okmányiroda Battonyán, Mezőhegyesen és Mezőkovácsházán, valamint ez utóbbi településen található a munkaügyi központ is.

A statisztikai kistérségi központot Mezökovácsháza tölti be. Ezen kistérséghez tartozik Medgyesegyháza, Mezőhegyes és Battonya is. Tótkomlós az Orosházi kistérséghez köthetö.

A települések több kistérségi társulásban is részt vesznek. Ilyen például a Marosháti Kistérség Turizmusáért Egyesület, melynek Mezöhegyes, Tótkomlós és Mezőkovácsháza a tagjai. Az egyesület célja a kistérségi települések turisztikai vonzerejének és idegenforgalmának növelése. Ennek érdekében az egyesület turisztikai irodát is üzemeltet Mezőhegyesen. Tótomlós más egyéb társulásokban is aktívan részt vesz. llyenek például az Orosházi Kistérség Többcélú Társulása, Tótkomlós és Térsége Állati Hulladék Kezelési Önkormányzati Társulás vagy a Hét Határon Átnyúló Önkormányzati Szövetség. Tótkomlós kivételével az összes település tagja a Dél-Békési Kistérség Többcélú Társulásának.

Turizmus szempontjából mindegyik település kínál valami érdekességet. Battonyán igénybe vehető a városi wellness gyógyfürdő és a helyi panzióban szálláslehetőség is adódik. Medgyesegyházán megemlítendő a minden évben megrendeződő Dinnyefesztivál, amely évröl évre egyre több látogatót vonz. A program minden évben tartogat szakmai, családi és könnyüzenei programokat a kikapcsolódni vágyóknak. Az elszállásolás magánházaknál, 
illetve a rendezvény alatt a kijelölt kempingben lehetséges. Mezöhegyes a lovassportokkal kapcsolatos programokról híres. Egész évben látogatható a Hotel Nonius, ahol lovaglással kapcsolatos programok bármikor igénybe vehetők. Érdemes megtekinteni a város régi gazdasági épületeit is. A település jelenleg is a Világörökség részének várományosa. Mezőkovácsházán turisztikai szempontból érdekes lehet a néhány éve felújított strandfürdő. Szállás megoldható a településen található két panzióban, illetve a fürdő melletti kempingben. Tótkomlóson szintén a fürdő fontos turisztikai célpont. Megszállni egy panzióban, illetve magánházaknál lehetséges.

1. térkép. A kistérség városainak vasúti hálózata és városi funkciói (jelmagyarázattal)
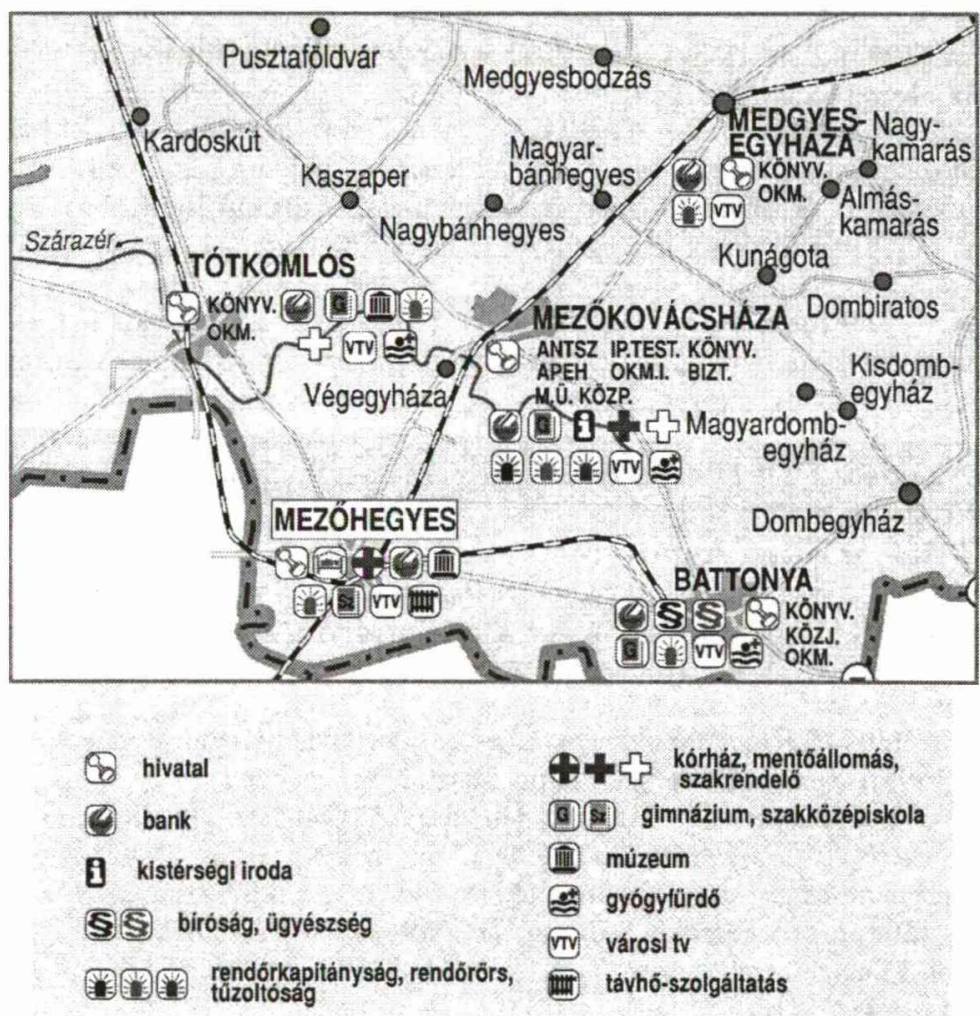

Forrás: Zsótér 2010 


\section{4.ÖSSZEFOGLALÁS}

A vizsgálat végeztével arra a következtetésre jutottam, hogy a városok funkciói nagymértékben nem változtak, a megosztottság továbbra is megmaradt. A funkciókban azonban változások is végbementek mind pozitív, mind negatív irányban egyaránt. Pozitiv iránynak nevezhetjük az idő előrehaladtával, és a technika fejlődésével bizonyos új funkciók megjelenését. Ilyenek például a bankfiókok, kábel tv szolgáltatás, vagy a turisztikai programok. Negatív iránynak tekinthetjük a funkcióbeli szükülést, mely legföképpen az egészségügyben ment végbe. Ezek az intézmények ma már csak a környékbeli nagyobb városokban, Orosházán, Békéscsabán és Gyulán találhatók meg.

\section{IRODALOMJEGYZÉK}

Beluszky P. (1999): The Hungarian Urban Network at the End of the Second Millenium, Nyomdaipari, Kereskedelmi és Szolgáltató Ltd., Pécs.

Dövényi Z. - Dövényi Zné (1982): A centrumok helyzete a dél-békési térség településhálózatában. Békési Élet. 1982. XVII. évfolyam 2. szám. Tudományos Ismeretterjesztő Társulat Békés megyei szervezete. Békéscsaba. pp.200-217.

Enyedi Gy. (1960): A Délkelet Alföld mezőgazdasági földrajza. Akadémia Kiadó. Budapest. pp.41-51.

Krajkó Gy. - Döbrönte Zné - Mészáros R. (1978): A települések közlekedésföldrajzi helyzete és a népesség mobilitása közötti összefüggés a Dél-Alföldön. Földrajzi Értesítő, 1978. XXVII. évfolyam, Magyar Tudományos Akadémia Földrajztudományi Kutató Intézet. Budapest. pp. 415-430.

Krajkó Gy. (szerk.) (1974): Békés megye gazdasági földrajza. Békés Megyei Tanács Végrehajtó Bizottsága. Békéscsaba.

Kvale S. (1996): Az interjú. Jószöveg Mühely Kiadó. Budapest.

Maday P. (1960): Békés megye története. Békés Megye Tanácsa V. B. Békéscsaba.

Mucsi Tné (2001): Mezökovácsháza. Color-Print Bt.. Mezökovácsháza.

Schleicher N. (2007.): Kvalitativ kutatási módszerek a társadalomtudományokban. RO-LA Kft. Budapest. pp. 38-53.

Szokolszky Á. (2004): Kutatómunka a pszichológiában. Osiris Kiadó. Budapest pp. 86-87.

Takács L. (1998): Historia Battonya. Petrina László. Mezőhegyes.

Zsótér B. - Gálné Horváth I. - Szabóné Türkössy A. (2008): Egy kábeltelevíziós társaság vagyoni helyzetének vizsgálata (2003-2006) egy vidéki város, Mezőhegyes életében. Jelenkori társadalmi és gazdasági folyamatok. IV. évf. 1. sz. pp.67-71. ISSN 1788-7593.

Zsótér B. (2007): Examination of Hotel Nonius. Management of Durable Rural Development. Management Agricol. Timisoara. EDITURA AGROPRINT TIMISOARA. pp. 571-574. ISSN 1453-1410.

Zsótér B. (2008): Változások a délkelet-alföldi Mezőhegyes életében várossá nyilvánítását követöen. Területi Statisztika. Budapest. 11. (48.) évfolyam 6. szám. pp.651-657. ISSN 0018-7828.

Zsótér B. (2010): Mezöhegyes - egy sajátos település útja az Alföldön. PhD értekezés. 